\title{
LUDNOŚĆ NA OBSZARACH WIEJSKICH WOJEWÓDZTWA OPOLSKIEGO - PRZESZŁOŚĆ I PERSPEKTYWY DEMOGRAFICZNE
}

\section{POPULATION IN RURAL AREAS OF THE OPOLSKIE VOIVODSHIP - DEMOGRAPHIC PAST AND FUTURE PROSPECTS}

\author{
Joanna DYBOWSKA \\ PIN - Instytut Śląski w Opolu \\ ul. Piastowska 17, 45-081 Opole \\ j.dybowska@instytutslaski.com
}

Zarys treści: Celem artykułu jest charakterystyka zmian w liczebności populacji mieszkańców obszarów wiejskich województwa opolskiego. Na podstawie danych pochodzących ze spisów powszechnych ludności przedstawiono liczbę mieszkańców wsi badanego regionu w okresie około 60 lat, z uwzględnieniem zmian w podziale administracyjnym kraju. Najnowsza prognoza liczby ludności Polski na lata 2014-2050 opublikowana przez GUS w październiku 2014 r. pozwoliła na wydłużenie okresu analizy o kolejne 40 lat. W artykule poruszony został problem migracji czasowych i ich wpływu na jakość informacji o stanie ludności w regionie migracyjnym, jakim jest Śląsk Opolski ${ }^{1}$. Przedstawiono też ocenę wyników prognozy dla województwa opolskiego w kontekście przyjęcia zawyżonych stanów ludności faktycznej jako podstawy dla przygotowania długoterminowej prognozy.

Słowa kluczowe: obszary wiejskie, depopulacja, czasowe migracje zagraniczne, ludność faktyczna, prognoza.

\section{Liczba ludności w przekroju miasto-wieś w latach 1950-2011}

Województwo opolskie, utworzone w 1950 r. na ziemiach przyłączonych do Polski w 1945 r., w obecnym podziale administracyjnym kraju jest najmniejszą jednostką pod względem liczby mieszkańców i obszaru. Zaliczane jest także do słabiej zurbanizowanych regionów. Ludność zamieszkująca obszary wiejskie dominowała w populacji województwa opolskiego do 1981 r., wówczas wskaźnik urbanizacji przekroczył 50\% i do chwili obecnej uległ niewielkim zmianom. Mieszkańcy wsi stanowili zatem znaczną część zasobów demograficznych Śląska Opolskiego i jak pokazuje najnowsza prognoza liczby ludności

${ }^{1} \mathrm{~W}$ artykule zamiennie używany będzie termin Śląsk Opolski i województwo opolskie, choć pojęcia te nie są tożsame. Analizowane dane w długim okresie odnoszą się do obszaru województwa wyznaczonego granicami administracyjnymi z lat 1975-1998 (stały obszar) oraz obecnymi granicami obowiązującymi od 1 stycznia 1999 r. 
Polski do 2050 r., ich udział w ogólnej populacji regionu będzie wzrastał, gdyż depopulacja będzie szybciej postępowała wśród mieszkańców miast aniżeli wśród mieszkańców wsi (Prognoza ludności... 2014).

Zmiany w podziale administracyjnym kraju pociągające za sobą zmiany obszarów, dla których gromadzone są dane m.in. w zakresie statystyki ludności, utrudniają obserwację procesów demograficznych w długim okresie na podstawie publikowanych przez GUS danych statystycznych. W tabelach 1 i 2 przedstawiono liczbę mieszkańców województwa opolskiego w podziale na miasto i wieś na tle zmian zaludnienia w tym samym układzie dla całego kraju w latach 1950-2011. Tabela 1 zawiera dane dla województwa opolskiego wyznaczonego granicami administracyjnymi z lat 1975-1998², natomiast tabela 2 dla województwa w aktualnych granicach obowiązujących od 1 stycznia 1999 r.

Tabela 1. Ludność Polski i województwa opolskiego w latach 1950-1988 (w tys.)

\begin{tabular}{|l|c|c|c|c|c|}
\hline \multicolumn{7}{|c|}{ Wyszczególnienie } & 1950 & 1960 & 1970 & 1978 & 1988 \\
\hline \multicolumn{7}{|c|}{ Polska $^{\mathrm{a}}$} \\
\hline Ogółem & $25008^{\mathrm{b}}$ & $29776^{\mathrm{b}}$ & 32642 & 35061 & 37879 \\
Miasto & 9605 & 14206 & 17064 & 20150 & 23175 \\
Wieś & 15009 & 15200 & 15578 & 14911 & 14704 \\
\hline Wieś w \% ludności ogółem & 61,0 & 51,0 & 47,7 & 42,5 & 38,8 \\
\hline \multicolumn{7}{|c|}{ Województwo opolskie ${ }^{\text {c }}$} & & \\
\hline Ogółem & 706,1 & 816,3 & 928,7 & 969,1 & 1013,5 \\
Miasto & 228,1 & 314,3 & 408,9 & 469,3 & 527,0 \\
Wieś & 478,0 & 502,0 & 519,8 & 499,8 & 486,5 \\
\hline Wieś w \% ludności ogółem & 67,7 & 61,5 & 56,0 & 51,6 & 48,0 \\
\hline
\end{tabular}

${ }^{a}$ według spisów powszechnych, ${ }^{b}$ wielkości niezbilansowane $w$ podziale miasto-wieś, ${ }^{\mathrm{c}} \mathrm{W}$ granicach administracyjnych z lat 1975-1998.

Źródło: opracowanie własne na podstawie: Rocznik Demograficzny 2014, Narodowy Spis Powszechny 1978.

Oceniając w długim okresie stan ludności województwa opolskiego na jego stałym obszarze, można stwierdzić, że do lat 80. XX w. mieliśmy do czynienia ze wzrostem liczby mieszkańców, który obejmował dynamiczny wzrost liczby mieszkańców miast (więcej niż podwojenie w latach 1950-1988) i niewielki przyrost liczby mieszkańców wsi, który trwał do lat 70. XX w. Trzeba pamiętać jednak, że na dynamiczny wzrost liczby mieszkańców miast miał wpływ nie tylko dodatni przyrost naturalny i dodatnie saldo migracji wewnętrznych, ale też decyzje administracyjne (zmiany granic miast czy statusu miejscowości).

Obszary wiejskie, które w całym powojennym okresie rozwoju demograficznego w województwie opolskim, jak i w całym kraju, charakteryzowały się wyższą aniżeli obszary miejskie dzietnością kobiet, były naturalnym zapleczem dla wzrostu demograficznego miast w efekcie migracji ludności ze wsi do miast. Pomimo lepszych parametrów wymiany pokoleń na obszarach wiejskich liczba ludności wsi wykazywała niższą dynamikę aniżeli liczba mieszkańców miast.

\footnotetext{
2 Jest to obszar, który stale znajdował się w granicach województwa opolskiego i stanowi on 91\% obecnego obszaru. Różni się od niego o ziemie powiatu oleskiego z wyłączeniem gminy Zębowice (zob. ryc. 1).
} 
Tabela 2. Ludność Polski i województwa opolskiego w latach 1988-2011 (w tys.)

\begin{tabular}{|c|c|c|c|}
\hline Wyszczególnienie & 1988 & 2002 & 2011 \\
\hline \multicolumn{4}{|c|}{ Polska $^{a}$} \\
\hline Ogółem & 37879 & 38230 & 38512 \\
\hline Miasto & 23175 & 23610 & 23406 \\
\hline Wieś & 14704 & 14620 & 15106 \\
\hline Wieś w \% ludności ogółem & 38,8 & 38,2 & 39,2 \\
\hline \multicolumn{4}{|c|}{ Województwo opolskie } \\
\hline Ogółem & 1080,7 & 1065,0 & 1016,2 \\
\hline Miasto & 552,0 & 560,1 & 532,2 \\
\hline Wieś & 528,7 & 504,9 & 484,0 \\
\hline Wieś w \% ludności ogółem & 48,9 & 47,4 & 47,6 \\
\hline
\end{tabular}

${ }^{a}$ według spisów powszechnych, ${ }^{b}$ w granicach administracyjnych obowiązujących od 1 stycznia1999 r. Źródło: opracowanie własne na podstawie: Narodowy Spis Powszechny Ludności i Mieszkań... (2003), Ludność w województwie opolskim... (2013).

Największa liczba mieszkańców wsi notowana była na stałym obszarze województwa opolskiego na przełomie lat 60. i 70. XX w. (Drobek i Heffner 1992), natomiast liczba mieszkańców miast wzrastała jeszcze do pierwszych lat XXI w., a ogólna liczba mieszkańców województwa do lat 80. XX w. (Dybowska 2013). Obszary wiejskie województwa opolskiego niejednokrotnie były przedmiotem badań, które wskazywały na problemy depopulacyjne (Heffner 1990, 1991; Drobek i Heffner 1992; Szczygielski 1990) nie tylko w efekcie migracji do miast, jak w innych regionach kraju, ale również w wyniku intensywnej emigracji (Rauziński 1991). Badania nad stanem ludności w przekroju terytorialnym województwa opolskiego ujawniły, że wzrost liczby ludności wsi miał raczej punktowy charakter, natomiast depopulacja strefowy (Heffner 1991). Strefa koncentracji wiejskich jednostek osadniczych charakteryzujących się stałą depopulacją obejmowała już w latach 1970-1990 środkowo-wschodnią część Płaskowyżu Głubczyckiego oraz północną część regionu. Śląsk Opolski zaliczany był wówczas do regionów o stosunkowo silnych procesach wyludniania się wsi z tendencją nasilania się tego procesu (Heffner 1991). Dalszy przebieg procesów demograficznych na Śląsku Opolskim pokazał, że problem zmniejszania się liczby ludności nie dotyczy już tylko wybranych obszarów wiejskich, ale objął ogólną populację mieszkańców, w tym i mieszkańców miast. Na stałym obszarze województwa, biorąc pod uwagę emigrację nierejestrowaną ${ }^{4}$ w ewidencji bieżącej ludności, ogólna liczba mieszkańców najprawdopodobniej nigdy nie przekroczyła $1 \mathrm{mln}$, choć taki stan ludności podaje spis powszechny dla 1988 r. Trzeba jednak zauważyć, że w liczbie 1,013 m/n zawarte jest 53 tys. długoterminowych migrantów czasowych, którzy przedłużyli swój czas pobytu za granicą poza zadeklarowany czas wyjazdu i do momentu krytycznego spisu

\footnotetext{
${ }^{3}$ Badania przeprowadzone przez W. Drobka i K. Heffnera dla lat 1950-1990 wykazały, że na obszarze województwa w granicach z lat 1975-1998 w latach 70. XX w. była największa średnia wielkość wiejskiej jednostki osadniczej oraz najwięcej wsi największych - powyżej 2 tys. mieszkańców. Wsi najmniejszych, liczących poniżej 50 mieszkańców, nie było w momencie utworzenia województwa jako samodzielnej jednostki, pojawiły się one dopiero w latach 80. XX w.

${ }^{4}$ Chodzi o znacznych rozmiarów emigrację pod pozorami wyjazdów turystycznych, z którą mieliśmy do czynienia w latach 70. i 80. XX w.

${ }^{5}$ Jest to wielkość dla obszaru województwa w ówczesnych granicach administracyjnych.
} 
nie powrócili do kraju (Sakson 2002). Według danych następnych spisów liczba ludności faktycznej na tym obszarze wynosiła w 2002 r. 999,3 tys. osób (528,9 tys. w miastach i 470,4 tys. na wsi), a w 2011 r. 953,7 tys. osób (500,1 tys. w miastach, 453,6 tys. na wsi).

W aktualnych granicach województwa, dla których jako punkt odniesienia podano przeliczone dane spisu powszechnego z 1988 r., widoczne jest zmniejszanie się ogólnej liczby mieszkańców regionu w latach 2002-2011. Ostatni spis powszechny Polski był dla województwa opolskiego w aktualnych jego granicach już z kolei trzecim, który wykazał zmniejszanie się liczby ludności. W latach 2002-2011 ubytek ludności faktycznej w województwie o 4,58\% był największy w skali kraju. Spadek liczby ludności nastąpił również w województwach: łódzkim o 2,84\%, śląskim o 2,37\%, świętokrzyskim o 1,29\%, lubelskim o $1,06 \%$ i podlaskim o $0,51 \%$.

\section{Ludność na obszarach wiejskich w przekroju powiatów województwa opolskiego w latach 2002-2011}

Województwo opolskie jako jednostka administracyjna obejmuje 12 powiatów, w tym 11 ziemskich i 1 grodzki, gdyż stolica regionu Opole jest miastem na prawach powiatu (ryc. 1). Jak wcześniej wspomniano, ludność obszarów wiejskich stanowi znaczną część zasobów demograficznych województwa - nieco mniej niż 50\%. Jednak w układzie przestrzennym mamy do czynienia z przewagą ludności na obszarach wiejskich w 5 powiatach: opolskim, oleskim, namysłowskim, strzeleckim i głubczyckim. W powiecie opolskim, który jest największym pod względem obszaru i drugim po powiecie nyskim pod względem liczby ludności, mieszkańcy wsi według NSP 2011 stanowili 86\% ogółu ludności. (zob. tab. 3)

Tabela 3. Mieszkańcy powiatów w województwie opolskim w 2002 i 2011 r.

\begin{tabular}{|c|c|c|c|c|c|c|c|}
\hline \multirow{3}{*}{ Obszar } & \multicolumn{3}{|c|}{2002} & \multicolumn{3}{|c|}{2011} & \multirow{3}{*}{$\begin{array}{c}\begin{array}{c}\text { Wieś: } \\
\text { dynamika }\end{array} \\
2011 / 2002 \\
\%\end{array}$} \\
\hline & \multirow{2}{*}{$\begin{array}{c}\text { ogółem } \\
\text { liczba }\end{array}$} & \multicolumn{2}{|c|}{ wieś } & \multirow{2}{*}{$\begin{array}{c}\text { ogółem } \\
\text { liczba }\end{array}$} & \multicolumn{2}{|c|}{ wieś } & \\
\hline & & liczba & $\%$ & & liczba & $\%$ & \\
\hline Województwo ${ }^{a}$ & 1065043 & 504979 & 47,4 & 1016212 & 483995 & 47,6 & 95,8 \\
\hline \multicolumn{8}{|l|}{ Powiaty ${ }^{b}$} \\
\hline Brzeski & 92857 & 39109 & 42,1 & 92505 & 40130 & 43,4 & 102,6 \\
\hline Kluczborski & 71464 & 34814 & 48,7 & 68040 & 33193 & 48,8 & 95,3 \\
\hline Namysłowski & 44481 & 27642 & 62,1 & 43183 & 27114 & 62,8 & 98,1 \\
\hline Nyski & 148059 & 68836 & 46,5 & 142581 & 67244 & 47,2 & 97,7 \\
\hline Prudnicki & 61897 & 29121 & 47,0 & 57837 & 27246 & 47,1 & 93,6 \\
\hline Głubczycki & 51795 & 28127 & 54,3 & 48453 & 25933 & 53,2 & 92,2 \\
\hline Kędzierzyńsko-kozielski & 104728 & 37631 & 35,9 & 98701 & 34548 & 35,0 & 91,8 \\
\hline Krapkowicki & 70081 & 31329 & 44,7 & 65872 & 29791 & 45,2 & 95,1 \\
\hline Oleski & 69981 & 44041 & 62,9 & 66288 & 42033 & 63,4 & 95,4 \\
\hline Opolski & 136572 & 119267 & 87,3 & 133137 & 114316 & 85,9 & 95,8 \\
\hline Strzelecki & 83182 & 45062 & 54,2 & 76990 & 42447 & 55,1 & 94,2 \\
\hline
\end{tabular}

${ }^{a}$ w aktualnych granicach, ${ }^{b}$ bez Opola, które jest miastem na prawach powiatu.

Źródło: opracowanie własne na podstawie: Ludność w województwie opolskim... (2013). 


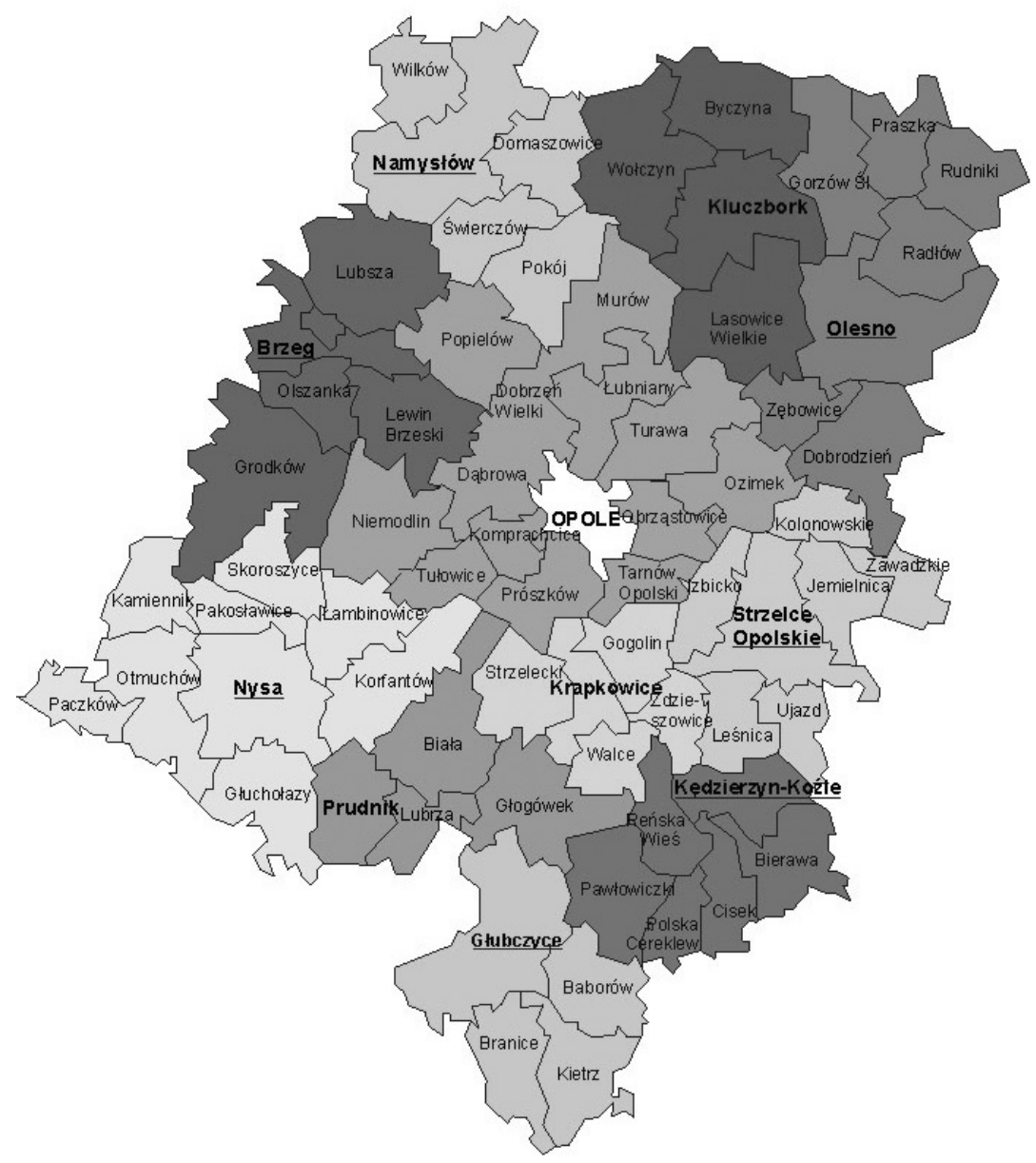

Ryc. 1. Podział administracyjny województwa opolskiego obowiązujący od 1 stycznia 1999 r.

Administrative division of the Opolskie Voivodship binding since January 1, 1999.

Źródło: Załącznik nr 1 do Statutu Województwa Opolskiego, Uchwała Sejmiku Województwa Opolskiego z dnia 27 czerwca $2000 \mathrm{r}$.

http://www.infor.pl/monitor-polski, rok, 2000,nr, 22/(17.05.2014).

Source: Appendix no.1 to the Statute of the Opolskie Voivodship, Resolution of the Opolskie Voivodship Regional Council of June 27, 2000.

Tak więc w centralnej części województwa opolskiego mamy do czynienia z dużą koncentracją ludności wiejskiej, gdyż powiat opolski obejmuje 13 gmin, z których 10 jest gminami wiejskimi i 3 gminami miejsko-wiejskimi, z niewielkimi miastami o charakterze centrów lokalnych (Niemodlin, Ozimek, Prószków6 ${ }^{6}$ ). Powiat opolski skupia 24\% ogółu ludności wiejskiej województwa opolskiego. W powiecie nyskim, pierwszym pod względem zaludnienia, zamieszkuje 14\% ogółu mieszkańców wsi. Kolejne pod względem liczby ludności na obszarach wiejskich powiaty strzelecki i oleski skupiają po około 9\% ogółu mieszkańców wsi województwa opolskiego.

${ }^{6}$ Miasto Prószków wydzielono z gminy Prószków z dniem 1 stycznia 2004 r. 
W okresie międzyspisowym 2002-2011 jedynie w powiecie brzeskim odnotowano niewielki o 2,6\% wzrost liczby ludności faktycznej na obszarach wiejskich - w pozostałych wystąpiły spadki, przy czym największy w powiecie kędzierzyńsko-kozielskim o 8,2\%, w głubczyckim o 7,8\%, w prudnickim o 6,4\% i w strzeleckim o 5,8\%. Trzeba jednak zaznaczyć, że w stosunku do wyników jeszcze wcześniejszego spisu ludności z 1988 r. miały już miejsce ubytki ludności na obszarach wiejskich we wszystkich powiatach oprócz opolskiego - największy, ponad 10\% ubytek dotyczył powiatów kędzierzyńsko-kozielskiego $(11,2 \%)$ i głubczyckiego (10,5\%) (NSP 2002... 2003).

\section{Emigranci czasowi wśród mieszkańców wsi województwa opolskiego}

Rozpatrując sytuację demograficzną w województwie opolskim trzeba pamiętać, że jest ono wyróżniającym się na tle kraju regionem migracyjnym. Od momentu utworzenia tej jednostki administracyjnej w 1950 r. ujemne saldo migracji, w efekcie intensywnej emigracji rodzimej ludności Śląska Opolskiego, było istotnym elementem bilansu liczby ludności zamieszkującej ten obszar. Utrzymująca się długotrwale dużych rozmiarów emigracja ze Śląska Opolskiego ma związek z historią tego regionu i specyfiką składu społecznego jego mieszkańców ukształtowaną w procesie zasiedlania ziem przyłączonych do Polski po zakończeniu II wojny światowej. Emigracja ludności rodzimej, dominującej w centralnej i wschodniej części województwa opolskiego, rzutowała na różnice sytuacji demograficznej w przekroju terytorialnym województwa, hamowała tempo wzrostu ogólnej liczby mieszkańców i wreszcie wprowadziła populację tego regionu w fazę depopulacji, która rozpoczęła się dużo wcześniej, aniżeli wystąpił ujemny przyrost naturalny (Dybowska 2013). Tak wiec emigracja była istotnym elementem bilansu ludności, choć trzeba zauważyć, że do 1988 r. na stałe emigrowała głównie ludność rodzima koncentrująca się właśnie na obszarach wiejskich. Wraz z transformacją ustrojową dominującą formą migracji zagranicznych stały się migracje o charakterze czasowym, w których najpierw uczestniczyła ludność rodzima dysponująca polskim i niemieckim obywatelstwem, a po przystąpieniu Polski do Unii Europejskiej w 2004 r. w emigracji czasowej w coraz większym stopniu uczestniczy ludność napływowa. Tak więc obecnie problem emigracji dotyczy zarówno rodzimych, jak i napływowych mieszkańców województwa opolskiego, choć wcześniejsza intensywna emigracja wśród ludności rodzimej przyśpieszyła proces depopulacji na znacznych obszarach województwa opolskiego, na których ta ludność dominuje. Specyfika emigracji z województwa opolskiego polegała na tym, że emigranci wywodzili się z ludności rodzimej i częściej byli to mieszkańcy wsi aniżeli miast. Ostatnie spisy ludności wykazały, że migranci czasowi z obszarów wiejskich przeważali wśród ogółu migrantów w 2002 r. w województwie opolskim (61\%), podkarpackim (56\%) i małopolskim (52\%), podczas gdy dla całego kraju migranci czasowi z obszarów wiejskich stanowili 38\%. W 2011 r. mieszkańcy wsi stanowili 34\% ogółu migrantów czasowych w Polsce i przeważali jedynie w województwie opolskim (53\%) i podkarpackim (53\%). Wobec tego w województwie opolskim w całym powojennym okresie obszary wiejskie dotknięte były odpływem ludności nie tylko w ramach migracji wewnętrznych (osiedlanie się w mieście tak jak w innych regionach kraju), ale również w ramach najintensywniejszej w skali Polski emigracji stałej (Solga 2002), a w obecnych warunkach na stan ludności mają również wpływ - oczywiście łącznie z ruchem naturalnym - migracje o charakterze czasowym, 
pośród których te długotrwałe można by traktować w kategorii ubytku ludności. W tabeli 4 przedstawiono natężenie migracji czasowej wśród mieszkańców wsi województwa opolskiego według danych spisów powszechnych z 2002 i 2011 r. W układzie przestrzennym województwa widoczne jest znacząco wyższe natężenia migracji długoterminowej (chodzi o osoby przebywające za granicą co najmniej 12 miesięcy i dłużej) w powiatach, w których koncentruje się ludność rodzima. W 2011 r. w stosunku do 2002 r. widoczne jest pewne obniżenie natężenia migracji długoterminowej dla całego województwa, jak i dla obszarów wiejskich, wynikające ze zmniejszenia liczby migrantów długoterminowych dla całego województwa z 89323 osób w 2002 r. do 80444 w 2011 r., a dla obszarów wiejskich z 55605 osób w 2002 r. do 42692 w 2011 r.

Tabela 4. Emigranci długookresowi w powiatach województwa opolskiego w 2002 i 2011 r. na 1000 mieszkańców

\begin{tabular}{|c|c|c|c|c|}
\hline \multirow{3}{*}{ Obszar } & \multicolumn{4}{|c|}{ Emigranci długookresowia na 1000 mieszkańców } \\
\hline & \multicolumn{2}{|c|}{2002} & \multicolumn{2}{|c|}{2011} \\
\hline & ogółem & wieś & ogółem & wieś \\
\hline Województwo opolskie & 84 & 110 & 79 & 88 \\
\hline \multicolumn{5}{|l|}{ Powiaty } \\
\hline Brzeski & 22 & 21 & 44 & 38 \\
\hline Kluczborski & 67 & 99 & 74 & 82 \\
\hline Namysłowski & 33 & 33 & 49 & 46 \\
\hline Nyski & 35 & 33 & 65 & 58 \\
\hline Prudnicki & 84 & 97 & 69 & 72 \\
\hline Głubczycki & 42 & 43 & 53 & 52 \\
\hline Kędzierzyńsko-kozielski & 107 & 168 & 83 & 100 \\
\hline Krapkowicki & 142 & 160 & 49 & 128 \\
\hline Oleski & 105 & 107 & 94 & 90 \\
\hline Opolski & 160 & 172 & 114 & 120 \\
\hline Strzelecki & 154 & 169 & 113 & 123 \\
\hline
\end{tabular}

a osoby przebywające czasowo za granicą 12 miesięcy i więcej według spisu powszechnego, b bez Opola, które jest miastem na prawach powiatu.

Źródło: obliczenia własne na podstawie danych spisu powszechnego 2002 i 2011.

Jak wcześniej zaznaczono, po przystąpieniu Polski do Unii Europejskiej ludność napływowa województwa opolskiego w coraz większym stopniu zaczęła uczestniczyć w czasowych migracjach zagranicznych. Wobec tego w powiatach charakteryzujących się dużą koncentracją tej ludności natężenie długoterminowej czasowej migracji w 2011 r. wzrosło w stosunku do 2002 r., natomiast w powiatach obejmujących gminy o dominacji ludności rodzimej uległo obniżeniu, nastąpiło też zmniejszenie różnicy pomiędzy najwyższym natężeniem (128 emigrantów długoterminowych na 1000 mieszkańców w powiecie krapkowickim) i najniższym (38 w powiecie brzeskim) w 2011 r. w stosunku do 2002 r. (odpowiednio 172 powiat opolski i 21 powiat brzeski). Problem długotrwałej nieobecności mieszkańców województwa opolskiego w miejscu stałego zameldowania sięga wielu lat wstecz, do lat 70. XX w., kiedy to zliberalizowano przepisy prawa paszportowego i część osób chcących opuścić na stałe Polskę czyniła to pod pozorami 
wyjazdów turystycznych. Spis powszechny z 1988 r. wykazał 55025 mieszkańców województwa opolskiego nieobecnych w momencie krytycznym spisu z powodu wyjazdu za granicę, przez czas dłuższy do zadeklarowanego przed wyjazdem, co w ówczesnych warunkach było równoznaczne z naruszeniem przepisów prawa obowiązujących w PRL (Sakson 2002). Wśród nich 53895 osób nieobecna była już co najmniej 12 miesięcy. Kolejny spis powszechny, przeprowadzony w nowych warunkach społeczno-ekonomicznych w 2002 r., wykazał 105246 osób nieobecnych ponad 2 miesiące (wśród których 89323 było nieobecnych co najmniej 12 miesięcy, 21\% spośród nich wyjechało z Polski w 1988 r. i wcześniej, a prawie 54\% była już nieobecna prawie 10 lat) (Dybowska 2013). Ostatni spis z 2011 r. ujawnił 107984 osób czasowo przebywających za granicą powyżej 3 miesięcy ${ }^{7}$. Jak widać z przytoczonych danych, problem czasowej, w tym i długookresowej, nieobecności części stałych (w rozumieniu osób zameldowanych na pobyt stały) mieszkańców województwa opolskiego ma poważne rozmiary i długotrwały charakter. W związku z tym oceniając rzeczywisty stan liczby ludności w województwie opolskim czy w mniejszych jego jednostkach administracyjnych, należałoby uwzględniać informacje o migrantach czasowych ${ }^{8}$ przede wszystkim długotrwale nieobecnych. Jest to ważne zagadnienie związane z przydatnością kategorii ludności faktycznej do opisu stanu ludności w sytuacji wzrostu znaczenia emigracji o charakterze czasowym. (Dybowska 2012, 2013; Dybowska i Widera 2015; Rauziński i Szczygielski 2015).

Tabela 5. Ludność faktyczna i bez emigrantów długookresowych w województwie opolskim

\begin{tabular}{|c|c|c|c|c|c|c|}
\hline \multirow{3}{*}{ Obszar } & \multicolumn{6}{|c|}{ Wieś } \\
\hline & \multicolumn{3}{|c|}{2002} & \multicolumn{3}{|c|}{2011} \\
\hline & $\mathbf{L F}^{\mathbf{a}}$ & LF-Em ${ }^{b}$ & $\begin{array}{c}\text { LF-Em } \\
\text { (w \% LF) }\end{array}$ & LF $^{a}$ & LF-Em ${ }^{b}$ & $\begin{array}{c}\text { LF-Em } \\
\text { (w \% LF) }\end{array}$ \\
\hline Województwo opolskie & 504979 & 449374 & 89 & 483995 & 441303 & 91 \\
\hline \multicolumn{7}{|l|}{ Powiaty } \\
\hline Brzeski & 39109 & 38295 & 98 & 40130 & 38601 & 96 \\
\hline Kluczborski & 34814 & 31370 & 90 & 33193 & 30478 & 92 \\
\hline Namysłowski & 27642 & 26739 & 97 & 27114 & 25866 & 95 \\
\hline Nyski & 68836 & 66540 & 97 & 67244 & 63339 & 94 \\
\hline Prudnicki & 29121 & 26305 & 90 & 27246 & 25277 & 93 \\
\hline Głubczycki & 28127 & 26925 & 96 & 25933 & 24587 & 95 \\
\hline Kędzierzyńsko-kozielski & 37631 & 31305 & 83 & 34548 & 31108 & 90 \\
\hline Krapkowicki & 31329 & 26316 & 84 & 29791 & 25973 & 87 \\
\hline Oleski & 44041 & 39347 & 89 & 42033 & 38268 & 91 \\
\hline Opolski & 119267 & 98792 & 83 & 114316 & 100590 & 88 \\
\hline Strzelecki & 45062 & 37440 & 83 & 42447 & 37216 & 88 \\
\hline
\end{tabular}

a ludność faktyczna według spisu powszechnego, b ludność faktyczna bez emigrantów długookresowych (osób przebywających za granicą 12 miesięcy i więcej).

Źródło: opracowanie własne na podstawie danych spisu powszechnego 2002 i 2011.

7 Przy okazji ostatniego spisu powszechnego ludności w Polsce wydłużono do 3 miesięcy czas nieobecności kwalifikujący daną osobę do kategorii migranta czasowego. Niestety dane o czasie wyjazdu nie są miarodajne, gdyż na 80443 migrantów długoterminowych nie ustalono czasu wyjazdu dla 66411 osób.

8 Dane takie można uzyskać w ramach spisu powszechnego ludności. 
Ze względu na ograniczone ramy opracowania problem ten nie może być w tym miejscu szerzej omówiony, jednakże w tabeli 5 przedstawiono wyniki obliczeń korygujących liczbę ludności faktycznej o długotrwałych emigrantów czasowych. GUS, ustalając stan ludności faktycznej, nie bierze pod uwagę liczby osób czasowo nieobecnych z powodu wyjazdu za granicę. Bilansowane jest jedynie saldo migracji na pobyt stały, a na pobyt czasowy jedynie w ramach migracji wewnętrznych. Z tego też powodu kategoria ludności faktycznej, w zamierzeniu mająca oddawać wpływ migracji wewnętrznych na liczbę ludności w poszczególnych jednostkach administracyjnych, staje się niewystarczająca do badania stanu ludności na obszarach zarówno napływu, jak i odpływu w ramach czasowych migracji międzynarodowych ${ }^{9}$. Na przykładzie województwa opolskiego, które od lat jest regionem intensywnego odpływu w ramach migracji zagranicznych, widać jak bardzo na obszarach, na których występuje duża intensywność migracji czasowych, stan ludności faktycznej publikowany w ramach statystyki ludności różni się od rzeczywistego. Poznanie tego stanu jest możliwe po wykorzystaniu danych ze spisu powszechnego o czasowych migrantach zagranicznych. Ostrożna korekta jedynie o liczbę osób nieobecnych w miejscu zameldowania 12 miesięcy i więcej prowadzi do rozbieżności dla ogółu obszarów wiejskich o około 9\%. W powiatach „tradycyjnie migracyjnych” według ostatniego spisu ludności rozbieżność ta wyniosła ponad 10\% (krapkowicki 13\%, opolski i oleski po 12\%). W przedstawionych wynikach uwzględniono jedynie liczbę czasowych emigrantów, gdyż to głównie ona rzutuje na powstawanie znacznych rozbieżności pomiędzy oficjalnymi danymi na temat ludności a jej rzeczywistym stanem. Liczba długookresowych imigrantów czasowych przebywających na obszarach wiejskich województwa opolskiego jak na razie jest znikoma ${ }^{10}$, również reemigracja jest niewielka (Solga 2014).

Zgodnie z zaleceniami dla badań demograficznych w krajach europejskich GUS ${ }^{11}$ podjął się ustalania liczby ludności rezydującej jako kategorii uwzględniającej informacje o imigrantach długotrwale przebywających na danym terenie, jak i czasowych emigrantach długotrwale nieobecnych. Dane na temat tej kategorii ludności w Polsce zostały 20 kwietnia 2015 r. zamieszczone na stronie internetowej GUS. Problem jednak polega na tym, że podane liczby są co najmniej dyskusyjne i dotyczą obszaru całego województwa ${ }^{12}$. Dla województwa opolskiego podano, że na dzień 31 grudnia 2011 r. liczba ludności rezydującej wyniosła $969541^{13}$. Wiadomo jednak z ostatniego spisu, że w momencie krytycznym przy liczbie ludności faktycznej wynoszącej 1016212 osób, 80444 osoby były nieobecne przez co najmniej 12 miesięcy, a liczbę imigrantów długotrwale przebywających ustalono na 638 osób.

\footnotetext{
${ }^{9}$ W praktyce będzie ona również mało przydatna nawet dla uchwycenia czasowych migracji wewnętrznych na podstawie danych rejestrów administracyjnych, jeśli nie będzie dopełniany obowiązek meldunkowy, a tak na ogół się dzieje.

10 Spis powszechny z 2002 r. wykazał 379 imigrantów przebywających czasowo powyżej 2 miesięcy na obszarach wiejskich województwa opolskiego (w tym 146 cudzoziemców przebywających długotrwale), a spis z 2011 r. 427 imigrantów przebywających czasowo na obszarach wiejskich, w tym 229 przebywających długotrwale.

11 Zgodnie z Rozporządzeniem PE i Rady Nr 763/2008 to kategoria ludności rezydującej jest obowiązująca w porównaniach międzynarodowych (zob. Wyniki wstępne narodowego Spisu Powszechnego Ludności...2011).

12 Brak jest danych obejmujących mniejsze jednostki podziału administracyjnego.

13 Stan tej kategorii ludności wynosił odpowiednio dla miast 515321 osób, dla wsi 454220 osób.
} 
Podana wielkość ludności rezydującej dla województwa opolskiego wydaje się być znacznie zawyżona ${ }^{14}$. Warto zatem dane o skorygowanej o emigrantów czasowych liczbie ludności faktycznej w poszczególnych powiatach zamieszczone w tabeli 5 wziąć pod uwagę w konfrontacji z wynikami najnowszej prognozy GUS dotyczącej stanu ludności Polski w perspektywie 2050 roku.

\section{Elementy ruchu ludności na obszarach wiejskich w latach 2002-2013}

Zanim zostaną omówione wyniki najnowszej prognozy GUS, w kolejnych tabelach przedstawiono elementy ruchu ludności w województwie opolskim na tle danych charakteryzujących tendencje ogólnopolską w latach poprzedzających okres prognozowany. Jest to o tyle ważne, że rozpoznanie tendencji demograficznych w okresie poprzedzającym czas prognozy jest niezbędne dla przyjęcia założeń do dalszego możliwego przebiegu procesów demograficznych. Dane zawarte w tabelach 6 i 7 pokazują, że przebieg procesów demograficznych na obszarach wiejskich w województwie opolskim w latach 2002-2013 był mniej korzystny z punktu widzenia wartości współczynników charakteryzujących mieszkańców obszarów wiejskich w całym kraju. Obniżanie się płodności w kraju doprowadziło do wystąpienia po raz pierwszy w Polsce w 2002 r. ujemnego przyrostu naturalnego, który jednak dotyczył mieszkańców miast, gdyż dla mieszkańców obszarów wiejskich utrzymał się do chwili obecnej dodatni przyrost naturalny. Niestety na Śląsku Opolskim zarówno dla całego województwa, jak i dla obszarów wiejskich utrzymuje się ujemny przyrost naturalny ${ }^{15}$, który w ostatnich latach ma tendencję pogłębiającą się. W związku z tym wskaźnik dynamiki demograficznej dla obszarów wiejskich w Polsce wykazuje ciągle jeszcze przewagę urodzeń nad zgonami, natomiast na obszarach wiejskich w województwie opolskim występuje przewaga zgonów nad urodzeniami. Z kolei wskaźnik dzietności teoretycznej zarówno w kraju, jak i na obszarach wiejskich województwa opolskiego wykazuje typ reprodukcji niegwarantujący już prostej zastępowalności pokoleń, przy czym wartości dzietności teoretycznej na obszarach wiejskich województwa opolskiego są znacznie niższe od wartości dotyczących obszarów wiejskich w całym kraju.

Utrzymujący się w województwie opolskim ujemny przyrost naturalny działa na rzecz zmniejszania się liczby ludności, niestety współwystępuje on na obszarach wiejskich z ujemnym saldem migracji. W odróżnieniu od obszarów wiejskich w Polsce, które od 2000 r. odnotowują dodatnie ogólne saldo migracji i mają lepsze perspektywy demograficzne niż miasta (Rosner 2012), w województwie opolskim utrzymuje się ujemne saldo migracji, na co ma wpływ dużych rozmiarów emigracja stała. Zatem oba elementy bilansu liczby ludności przyrost naturalny, jak i saldo migracji powodują zmniejszanie się liczby ludności zamieszkującej obszary wiejskie Śląska Opolskiego. W nadchodzących latach, jak to przewiduje najnowsza prognoza GUS, proces depopulacji zarówno w województwie, jak i na jego obszarach wiejskich, będzie postępował.

\footnotetext{
14 Podobnie ma się sprawa z liczba ludności rezydującej dla całego kraju.

15 Po raz pierwszy ujemny przyrost naturalny w województwie opolskim zanotowany został w 2000 r. (na obszarach wiejskich po raz pierwszy w 1999 r. i systematycznie od 2001 r., dla miast po raz pierwszy w 2000 r. i corocznie od 2002 r.).
} 
Tabela 6. Natężenie przyrostu naturalnego i salda migracji na 1000 osób

\begin{tabular}{|c|c|c|c|c|c|c|c|c|}
\hline \multirow{3}{*}{ Rok } & \multicolumn{4}{|c|}{ Współczynnik przyrostu naturalnego } & \multicolumn{4}{|c|}{ Współczynnik salda migracji } \\
\hline & \multicolumn{2}{|r|}{ ogółem } & \multicolumn{2}{|r|}{ wieś } & \multicolumn{2}{|c|}{ ogółem } & \multicolumn{2}{|r|}{ wieś } \\
\hline & Polska & $\begin{array}{c}\text { województwo } \\
\text { opolskie }^{\mathrm{a}}\end{array}$ & Polska & $\begin{array}{c}\text { województwo } \\
\text { opolskie }^{\mathrm{a}}\end{array}$ & Polska & $\begin{array}{c}\text { województwo } \\
\text { opolskie }^{\mathrm{a}}\end{array}$ & Polska & $\begin{array}{c}\text { województwo } \\
\text { opolskie }^{\mathrm{a}}\end{array}$ \\
\hline 2002 & $-0,1$ & $-0,8$ & 0,7 & $-1,0$ & $-0,5$ & $-4,3$ & 1,0 & $-2,6$ \\
\hline 2003 & $-0,4$ & $-1,2$ & 0,2 & $-1,6$ & $-0,4$ & $-4,0$ & 1,9 & $-2,0$ \\
\hline 2004 & $-0,2$ & $-0,9$ & 0,3 & $-1,4$ & $-0,2$ & $-3,2$ & 2,7 & $-1,4$ \\
\hline 2005 & $-0,1$ & $-0,9$ & 0,3 & $-1,4$ & $-0,3$ & $-3,0$ & 2,0 & $-1,3$ \\
\hline 2006 & 0,1 & $-0,9$ & 0,6 & $-1,3$ & $-0,9$ & $-4,6$ & 1,7 & $-2,7$ \\
\hline 2007 & 0,3 & $-1,1$ & 0,8 & $-1,6$ & $-0,5$ & $-3,9$ & 2,8 & $-1,4$ \\
\hline 2008 & 0,9 & $-0,6$ & 1,5 & $-0,8$ & $-0,4$ & $-3,2$ & 2,3 & $-1,5$ \\
\hline 2009 & 0,9 & $-0,4$ & 1,2 & $-0,9$ & 0,0 & $-1,7$ & 2,8 & 0,6 \\
\hline 2010 & 0,9 & $-0,7$ & 1,4 & $-0,9$ & $-0,1$ & $-1,8$ & 3,1 & $-0,1$ \\
\hline 2011 & 0,3 & $-1,0$ & 0,8 & $-1,3$ & $-0,1$ & $-2,2$ & 2,6 & $-0,3$ \\
\hline 2012 & 0,0 & $-1,2$ & 0,7 & $-1,2$ & $-0,2$ & $-2,1$ & 2,2 & $-0,4$ \\
\hline 2013 & $-0,5$ & $-2,0$ & 0,2 & $-1,9$ & $-0,2$ & $-3,3$ & 2,1 & $-1,6$ \\
\hline
\end{tabular}

a $w$ aktualnych granicach.

Źródło: opracowanie własne na podstawie Roczników Demograficznych z lat 2003-2014.

Tabela 7. Współczynniki dynamiki demograficznej i dzietności

\begin{tabular}{|c|c|c|c|c|c|c|c|c|}
\hline \multirow{3}{*}{ Rok } & \multicolumn{4}{|c|}{ Współczynnik dynamiki demograficznej } & \multicolumn{4}{|c|}{ Współczynnik dzietności } \\
\hline & \multicolumn{2}{|r|}{ ogółem } & \multicolumn{2}{|r|}{ wieś } & \multicolumn{2}{|r|}{ ogółem } & \multicolumn{2}{|r|}{ wieś } \\
\hline & Polska & $\begin{array}{c}\text { województwo } \\
\text { opolskie }^{\mathrm{a}}\end{array}$ & Polska & $\begin{array}{c}\text { województwo } \\
\text { opolskie }^{\mathrm{a}}\end{array}$ & Polska & $\begin{array}{c}\text { województwo } \\
\text { opolskie }^{\mathrm{a}}\end{array}$ & Polska & $\begin{array}{c}\text { województwo } \\
\text { opolskie }^{a}\end{array}$ \\
\hline 2002 & 0,984 & 0,909 & 1,072 & 0,897 & 1,249 & 1,053 & 1,488 & 1,114 \\
\hline 2003 & 0,961 & 0,862 & 1,018 & 0,827 & 1,222 & 1,010 & 1,421 & 1,043 \\
\hline 2004 & 0,980 & 0,893 & 1,029 & 0,844 & 1,227 & 1,012 & 1,400 & 1,014 \\
\hline 2005 & 0,989 & 0,897 & 1,029 & 0,854 & 1,243 & 1,044 & 1,399 & 1,050 \\
\hline 2006 & 1,012 & 0,898 & 1,060 & 0,856 & 1,267 & 1,039 & 1,409 & 1,024 \\
\hline 2007 & 1,028 & 0,883 & 1,076 & 0,833 & 1,306 & 1,042 & 1,449 & 1,027 \\
\hline 2008 & 1,093 & 0,936 & 1,149 & 0,918 & 1,390 & 1,132 & 1,528 & 1,136 \\
\hline 2009 & 1,085 & 0,955 & 1,117 & 0,912 & 1,398 & 1,147 & 1,496 & 1,138 \\
\hline 2010 & 1,092 & 0,927 & 1,135 & 0,909 & 1,376 & 1,135 & 1,505 & 1,130 \\
\hline 2011 & 1,034 & 0,894 & 1,085 & 0,869 & 1,297 & 1,102 & 1,427 & 1,129 \\
\hline 2012 & 1,004 & 0,878 & 1,070 & 0,883 & 1,299 & 1,146 & 1,426 & 1,173 \\
\hline 2013 & 0,954 & 0,801 & 1,024 & 0,816 & 1,256 & 1,074 & 1,370 & 1,109 \\
\hline
\end{tabular}

${ }^{a}$ w aktualnych granicach.

Źródło: opracowanie własne na podstawie Roczników Demograficznych z lat 2003-2014. 


\section{Prognoza liczby ludności do 2050 r. w układzie miasto-wieś}

Przedstawione wcześniej współczynniki charakteryzujące ruch ludności oraz proces wymiany pokoleń świadczą o dużo bardziej niekorzystnej sytuacji demograficznej w województwie opolskim w stosunku do sytuacji występującej w kraju, niezależnie czy mamy na uwadze ogólną populację mieszkańców województwa, czy tylko mieszkańców obszarów wiejskich. Obserwowane w dłuższym czasie niekorzystne zmiany demograficzne w regionie opolskim, obejmujące zmniejszanie się liczby ludności, utrzymywanie się ujemnego przyrostu naturalnego i salda migracji, znajdują odbicie w wynikach prognozy, które powinny być alarmujące dla regionalnych i lokalnych włodarzy. Prognoza liczby ludności Polski na lata 2014-2050 wskazuje, że region opolski będzie obszarem kraju o największej depopulacji, której tempo będzie narastające do 2050 r.

Jak się okazuje, liczba ludności na obszarach wiejskich w Polsce może się utrzymać do 2050 r. na poziomie około 15 mln osób z tendencją wzrostową jeszcze do 2030 r., natomiast liczba mieszkańców miast w kraju będzie systematycznie maleć do poziomu 18,8 mln osób w 2050 r. (tab. 8). W regionie opolskim oczekiwane jest zmniejszanie się zarówno liczby mieszkańców miast, jak i wsi, przy czym tempo spadku liczby mieszkańców miast będzie znacząco wyższe (ubytek o 32\% w stosunku do 2011 r.) aniżeli mieszkańców wsi (ubytek o 20\%). Zmniejszanie się liczby ludności na obszarach wiejskich w obecnych granicach województwa opolskiego, które rozpoczęło się w latach 80. XX w., będzie postępować, ale jego przebieg w nadchodzących latach będzie relatywnie łagodniejszy aniżeli zmniejszanie się liczby mieszkańców miast, która wzrastała jeszcze do początku XXI w. i gwałtownie będzie zmniejszać się w relatywnie krótszym czasie (tab. 9).

Tabela 8. Prognoza liczby ludności w podziale miasto-wieś dla Polski i województwa opolskiego (w tys.)

\begin{tabular}{|c|c|c|c|c|c|c|}
\hline \multirow{2}{*}{ Wyszczególnienie } & \multicolumn{5}{|c|}{ Ludność w latach } & \multirow{2}{*}{$\begin{array}{l}\text { Dynamika zmian } \\
\text { liczby ludności } \\
2050 / 2011(\%)\end{array}$} \\
\hline & 2011 & 2020 & 2030 & 2040 & 2050 & \\
\hline \multicolumn{7}{|c|}{ Polska } \\
\hline Ogółem & 38512 & 38138 & 37185 & 35668 & 33951 & 88,2 \\
\hline Miasto & 23406 & 22717 & 21618 & 20234 & 18826 & 80,4 \\
\hline Wieś & 15106 & 15421 & 15567 & 15434 & 15125 & 100,1 \\
\hline Wieś w \% ludności ogółem & 39,2 & 40,4 & 41,9 & 43,3 & 44,5 & - \\
\hline \multicolumn{7}{|c|}{ Województwo opolskie } \\
\hline Ogółem & 1016,2 & 966,6 & 902,0 & 825,8 & 744,5 & 73,3 \\
\hline Miasto & 532,2 & 498,1 & 456,2 & 408,5 & 359,9 & 67,6 \\
\hline Wieś & 484,0 & 468,5 & 445,8 & 417,3 & 384,6 & 79,5 \\
\hline Wieś w \% ludności ogółem & 47,6 & 48,5 & 49,4 & 50,5 & 51,7 & - \\
\hline
\end{tabular}

Źródło: opracowanie własne na podstawie: Prognoza ludności... (2014), Ludność w województwie opolskim... (2013). 
Tabela 9. Zmiany prognozowanej liczby ludności w poszczególnych okresach w układzie miasto-wieś dla Polski i województwa opolskiego (w\%)

\begin{tabular}{|l|c|c|c|c|}
\hline \multirow{2}{*}{ Wyszczególnienie } & \multicolumn{3}{|c|}{ Lata } \\
\cline { 2 - 5 } & $\mathbf{2 0 2 0 - 2 0 1 1}$ & $\mathbf{2 0 3 0 - 2 0 2 0}$ & $\mathbf{2 0 4 0 - 2 0 3 0}$ & $\mathbf{2 0 5 0 - 2 0 4 0}$ \\
\hline \multicolumn{5}{|c|}{ Polska } \\
\hline Ogółem & 99,0 & 97,5 & 95,9 & 95,2 \\
Miasto & 97,1 & 95,2 & 93,6 & 93,0 \\
Wieś & 102,1 & 100,9 & 99,1 & 98,0 \\
\hline \multicolumn{7}{|c|}{ Województwo opolskie } & \\
\hline Ogółem & 95,1 & 93,3 & 91,6 & 90,2 \\
Miasto & 93,6 & 91,6 & 89,5 & 88,1 \\
Wieś & 96,8 & 95,2 & 93,6 & 92,2 \\
\hline
\end{tabular}

Źródło: opracowanie własne na podstawie: Prognoza ludności... (2014).

Jak już wcześniej zaznaczono, proces depopulacji będzie coraz szybciej pogłębiał się po 2020 r. z powodu przede wszystkim większej depopulacji wśród mieszkańców miast tak w kraju, jak i na Śląsku Opolskim.

\section{Prognoza liczby ludności do 2050 r. w powiatach województwa opolskiego}

Analizując oczekiwane zmniejszanie się liczby ludności województwa opolskiego (zob. tab. 10), warto zwrócić uwagę na przestrzenne zróżnicowanie tego procesu, bowiem największy ubytek liczby ludności na obszarach wiejskich przewidywany jest w powiecie głubczyckim (o 37\%) i w powiatach kędzierzyńsko-kozielskim (o 30\%), namysłowskim i prudnickim (o 28\%). Głębsza depopulacja wśród mieszkańców miast spowoduje, że wskaźnik urbanizacji ulegnie zmniejszeniu i ponownie mieszkańcy wsi będą przeważali wśród ludności województwa opolskiego. W układzie poszczególnych powiatów do 2050 r. przewidywana jest przewaga mieszkańców miast jedynie w powiatach kędzierzyńsko-kozielskim i brzeskim.

Dane zawarte w tabeli 10 obejmują wyniki prognozy zestawione ze stanem ludności faktycznej ustalonej w ostatnim spisie powszechnym ludności w 2011 r. Jak wcześniej zaznaczono, kategoria ludności faktycznej jest mało miarodajną dla badania stanu ludności w regionie migracyjnym, gdyż jej stan jest zawyżony w stosunku do rzeczywistej sytuacji. Rozbieżności są tym większe, im intensywniejsza jest na danym obszarze migracja o charakterze czasowym. Wprawdzie dzisiaj trudno przesądzić, czy obecna cała długoterminowa emigracja czasowa przekształci się w definitywną, ale niestety saldo migracji dla województwa opolskiego w prognozowanym okresie przewiduje przewagę odpływu nad napływem ludności. To znaczy, że w ocenie autorów prognozy saldo migracji w województwie opolskim, które do tej pory w przeważającej mierze wyznaczane było przez wyjazdy za granicę, będzie oddziaływało w kierunku zmniejszania się liczby ludności. Współwystępowanie ujemnego salda migracji z ujemnym przyrostem naturalnym nieuchronnie będzie pogłębiało proces depopulacji. Jednakże porównanie prognozowanych stanów ludności w przekroju powiatów województwa opolskiego z liczbą ludności faktycznej skorygowaną w 2011 r. o emigrantów długookresowych, wskazuje na to, że w powiatach 
namysłowskim, nyskim, prudnickim i głubczyckim już mamy do czynienia z liczbą ludności prognozowaną na rok 2020, w powiatach kluczborskim, kędzierzyńsko-kozielskim i oleskim ze stanami prognozowanymi do roku 2030, w powiatach brzeskim, krapkowickim i strzeleckim do roku 2040, a w powiecie opolskim stanu osiągniętego już w 2011 r. nie przewiduje się nawet do 2050 r. Tym samym na obszarach województwa opolskiego, na których mamy do czynienia z największymi rozbieżnościami w informacji o stanie ludności nawet w długiej perspektywie, nie jest widoczny ubytek ludności, który już wystąpił.

Tabela 10. Prognoza liczby ludności na obszarach wiejskich w powiatach województwa opolskiego

\begin{tabular}{|c|c|c|c|c|c|c|c|}
\hline \multirow[b]{2}{*}{ Obszar } & \multirow[b]{2}{*}{$2011^{a}$} & \multirow[b]{2}{*}{2020} & \multirow[b]{2}{*}{2030} & \multirow[b]{2}{*}{2040} & \multicolumn{3}{|c|}{2050} \\
\hline & & & & & liczba & $\begin{array}{l}\text { \% ogółu } \\
\text { ludności }\end{array}$ & 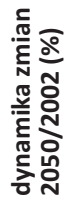 \\
\hline Województwo & 483995 & 468491 & 445864 & 417341 & 384632 & 52 & 79 \\
\hline \multicolumn{8}{|l|}{ Powiaty ${ }^{b}$} \\
\hline Brzeski & 40130 & 39879 & 39086 & 37580 & 35627 & 49 & 89 \\
\hline Kluczborski & 33193 & 31901 & 30094 & 27937 & 25498 & 53 & 77 \\
\hline Namysłowski & 27115 & 25795 & 24149 & 22017 & 19519 & 57 & 72 \\
\hline Nyski & 67244 & 64537 & 60876 & 55898 & 50139 & 52 & 75 \\
\hline Prudnicki & 27246 & 25570 & 23749 & 21763 & 19600 & 50 & 72 \\
\hline Głubczycki & 25934 & 23965 & 21737 & 19100 & 16306 & 51 & 63 \\
\hline Kędzierzyńsko-kozielski & 34548 & 32352 & 29770 & 27016 & 24128 & 36 & 70 \\
\hline Krapkowicki & 29791 & 28822 & 27343 & 25730 & 23958 & 52 & 80 \\
\hline Oleski & 42033 & 40668 & 38794 & 36480 & 33751 & 70 & 80 \\
\hline Opolski & 114315 & 113619 & 110641 & 106365 & 101130 & 85 & 88 \\
\hline strzelecki & 42446 & 41383 & 39625 & 37455 & 34980 & 63 & 82 \\
\hline
\end{tabular}

${ }^{a}$ dane rzeczywiste, ${ }^{b}$ bez Opola, które jest miastem na prawach powiatu.

Źródło: opracowanie własne na podstawie: Prognoza ludności... (2014).

\section{Podsumowanie}

W dotychczasowym przebiegu procesów demograficznych na obszarach wiejskich województwa opolskiego odpływ ludności w ramach migracji do miast (podobnie jak w całym kraju) oraz najintensywniejszej w skali kraju emigracji hamował rozwój liczebny populacji wiejskiej. Pomimo utrzymującego się do końca XX w. dodatniego przyrostu naturalnego liczba mieszkańców wsi wykazywała niższą dynamikę i krótszy okres wzrostu aniżeli liczba mieszkańców miast charakteryzujących się brakiem zastępowalności pokoleń dużo wcześniej aniżeli mieszkańcy wsi. W nadchodzących latach pierwszej połowy XXI w. przewiduje się na obszarach wiejskich Śląska Opolskiego dalsze zmniejszanie liczby ludności z 484 tys. w 2011 r. do 385 tys. w 2050 r. (czyli o ok. 20\%), ale będzie to i tak mniejszy ubytek niż wśród mieszkańców miast (o ok. 32\%). W sumie ludność województwa opolskiego 
poddana będzie najgłębszej depopulacji w skali kraju (o ok. 26\% w stosunku do ludności faktycznej w 2011 r.).

Trzeba jednak zaznaczyć, że kategoria ludności faktycznej jest mało przydatna do badania stanu ludności w regionie charakteryzującym się intensywnymi czasowymi migracjami zagranicznymi, jak to ma miejsce na Śląsku Opolskim. Liczba tej kategorii ludności w przypadku województwa opolskiego jest zawyżona w stosunku do ludności przebywającej rzeczywiście na tym obszarze. Dla prawidłowego zarządzania rozwojem regionu zagrożonego tak dużą depopulacją przydatne byłyby projekcje demograficzne odnoszące do kategorii ludności rezydującej a nie faktycznej.

\section{Literatura}

Drobek W., Heffner K., 1992, Infrastrukturalne i funkcjonalne czynniki przemian w wiejskiej sieci osadniczej Ślq̨ska Opolskiego, PIN - Instytut Śląski w Opolu, Opole.

Dybowska J., 2012, Migracja a stan ludności w województwie opolskim, [w:] R. Rauziński, T. Sołdra-Gwiżdż (red.), Społeczeństwo Ślqska Opolskiego 1945-2011-2035 - aspekty społeczne, demograficzne i rynku pracy, Ministerstwo Rozwoju Regionalnego, Opole-Warszawa s. 105-112.

Dybowska J., 2013, Przemiany demograficzne w regionie o nasilonej migracji zagranicznej na przykładzie województwa opolskiego, Uniwersytet Opolski, Opole.

Dybowska J., 2014, Depopulacja na obszarach wiejskich województwa opolskiego w latach 2002-2011, Journal of Agribusiness and Rural Development, 2 (32), s. 59-68.

Dybowska J., Widera K., 2015, Trudności w ocenie zmian zaludnienia Polski w zwiq̨zku z migracjami o charakterze czasowym, (maszynopis).

Heffner K., 1990, Przebieg procesów depopulacyjnych na Opolszczyźnie, [w:] K. Heffner (red.), Procesy wyludniania się wsi w regionie opolskim, PIN - Instytut Śląski w Opolu, Opole, s. 7-47.

Heffner K., 1991, Ślq̨sk Opolski. Proces przekształceń ludnościowych i przestrzennych systemu osadnictwa wiejskiego, PIN - Instytut Śląski w Opolu, Opole.

Ludność, ruch naturalny i migracje w województwie opolskim w 2006 r., 2007, Urząd Statystyczny w Opolu, Opole.

Ludność w województwie opolskim. Stan i struktura demograficzno-społeczna. Narodowy Spis Powszechny Ludności i Mieszkań 2011, 2013, Urząd Statystyczny w Opolu, Opole.

Migracje zagraniczne ludności. Narodowy Spis Powszechny Ludności i Mieszkań 2011, 2013, Urząd Statystyczny w Opolu, Opole.

Narodowy Spis Powszechny 1978, 1980, GUS, Warszawa.

Narodowy Spis Powszechny Ludności i Mieszkań 2002. Ludność. Stan oraz struktura demograficzna i społeczno-ekonomiczna. Województwo Opolskie, 2003, Urząd Statystyczny w Opolu, Opole.

Narodowy Spis Powszechny Ludności i Mieszkań 2002. Migracje ludności. Województwo Opolskie, 2004, Urząd Statystyczny w Opolu, Opole.

Prognoza ludności 2014-2050, 2014, GUS, Warszawa.

Rauziński R., Szczygielski K., 2015, Prognoza ludności dla województwa opolskiego do 2050 roku. Wnioski w kontekście prowadzenia polityki regionalnej oraz wsparcia odnowy demograficznej województwa opolskiego, Ekspertyza w ramach projektu pn. Opolskie Obserwatorium Terytorialne. Wzmocnienie systemu monitorowania polityk Publicznych (maszynopis).

Rauziński R., 1990, Ludność na Ślqsku 1945-1990, WSI, Opole.

Rocznik Demograficzny 2014, GUS, Warszawa. 
Rosner A., 2012, Aktualne tendencje zmian zaludnienia obszarów wiejskich, [w:] A. Rosner, (red.), Rozwój wsi i rolnictwa w Polsce. Aspekty przestrzenne i regionalne, Instytut Rozwoju Wsi i Rolnictwa Polskiej Akademii Nauk, Warszawa, s. 117-134.

Sakson B., 2002, Wpływ niewidzialnych migracji zagranicznych lat osiemdziesiq̨tych na struktury demograficzne Polski, SGH, Warszawa.

Solga B., 2002, Migracje polsko-niemieckie i ich konsekwencje społeczno-ekonomiczne na obszarach wiejskich Śląska Opolskiego, PIN - Instytut Śląski w Opolu, Opole.

Solga B., 2014, The Importance of International Return Migration In the Rural Development, [w:] W. Kamińska, K.Heffner (red.), Rural Development and EU Cohesion Policy, Studia Regionalne, 39, s. 101-112.

Szczygielski K., 1990, Zmiany zaludnienia Opolszczyzny w okresie powojennym, [w:] K. Heffner (red.), Procesy wyludniania się wsi w regionie opolskim, PIN - Instytut Śląski w Opolu, Opole, s. 49-66.

Wyniki wstępne narodowego Spisu Powszechnego Ludności i Mieszkań 2011, GUS 22 grudnia 2011 r., www.stat.gov.pl/cps/rde/xbcr/gus/lud_wyniki_wstepne_NSP_2011.pdf (styczeń 2012)

\section{Summary}

In the foregoing course of demographic processes in rural areas of the Opolskie Voivodship the population outflow within migration to towns (similar to the situation in the whole country) and the most intensive emigration in Poland stunted the growth of rural population. Despite the positive natural change which lasted till the end of the 20th century the number of rural population was showing lower dynamics and shorter growing period than urban population, characterized by the lack of replacing generations much earlier comparing to rural areas. In the first half of the 21st century it is predicted that in rural areas of the Opolskie Voivodship the population will decrease from 484 thous. in 2011 to 385 thous. people in 2050 (about 20\%), however this will still be a less pronounced decrease than in urban areas (about 32\%). As a result, the Opolskie Voivodship will experience the greatest depopulation in Poland (about $26 \%$ in comparison to de facto population in 2011).

However, it should be mentioned that the category of de facto population is not particularly useful in analyzing population size in a region characterized by intensive, temporal migrations abroad, as it takes place in the Opolskie Voivodship. The number of de facto population in this voivodship is overestimated in comparison to its real population size. Thus, demographic prospects concerning the category of resident population rather than de facto population would be more appropriate for managing the development of a region effectively, which is currently threatened by intensive, temporal migration outflow. 